\title{
Effect of long term soil fertilizer application on forms and distribution of potassium in soil under rice- cowpea cropping system
}

\section{DIVYA, B.R. JAGADEESH, D. K. SRINIVASA AND G. S. YOGESH}

\section{MEMBERS OF RESEARCH FORUM:}

Corresponding author :

D.K. SRINIVASA, Department of Soil Science and Agricultural Chemistry, College of Agriculture, G.K.V.K. University of Agricultural Sciences, BENGALURU (KARNATAKA) INDIA Email: Srinivasa.dk12@gmail.com

\section{Co-authors :}

M. DIVYA, Department of Soil Science and Agricultural Chemistry, College of Agriculture, G.K.V.K. University of Agricultural Sciences, BENGALURU (KARNATAKA) INDIA Email: divyagowda18@yahoo.in

B.R. JAGADEESH, Department of Soil Science, College of Agriculture (U.A.S.), HANUMANAHATTI (KARNATAKA) INDIA

Email: jagadeeshssac@ gmail.com

G. S. YOGESH, Krishi Vignana Kendra (U.A.S.) CHAMARAJNAGAR (KARNATAKA) INDIA Email: yogissac@gmail.com

Received : 30.01.2016; Revised : 16.03.2016; Accepted : 12.04.2016

\section{Summary}

An experiment was conducted at Zonal Agricultural Research Station, VC farm, Mandya to assess the effect of long term soil fertility management on behaviour of potassium with respect to different forms and distribution pattern in rice-cowpea cropping system. Soil of the study area belong to sandy loam texture having initial $\mathrm{pH}(6.28), \mathrm{EC}\left(0.14 \mathrm{dSm}^{-1}\right), \mathrm{CEC}(9.60$ cmol (p+) $\left.\mathrm{kg}^{-1}\right)$, MWHC (20.70\%) and bulk density (1.67 $\left.\mathrm{g} \mathrm{cc}^{-1}\right)$. The organic carbon (0.34 \%), available nitrogen (163 $\left.\mathrm{kg} \mathrm{ha}^{-1}\right)$, available potassium $\left(134 \mathrm{~kg} \mathrm{ha}^{-1}\right)$ were low and medium in available phosphorus $\left(29.20 \mathrm{~kg} \mathrm{ha}^{-1}\right)$. Results indicated that the water soluble $\mathrm{K}$ content of soils varied from 8 to $16 \mathrm{mg} \mathrm{K} \mathrm{kg}^{-1}$ in the surface layer and 5 to $14 \mathrm{mg} \mathrm{K} \mathrm{kg}^{-1}$ in the sub surface layer in the plots treated with different fertilizer, manure and their combinations. Exchangeable $\mathrm{K}$ also ranged between 59 and $116 \mathrm{mg} \mathrm{K} \mathrm{kg}^{-1}$ in the surface layer and 58 to $98 \mathrm{mg} \mathrm{K} \mathrm{kg}^{-1}$ in the sub surface layer. The non-exchangeable $\mathrm{K}$ content ranged from 111 to $874 \mathrm{mg} \mathrm{K} \mathrm{kg}{ }^{-1}$ and from 160 to $880 \mathrm{mg} \mathrm{K} \mathrm{kg}^{-1}$, respectively in the upper and the lower layers. The total $\mathrm{K}$ content varied from 792 to $3017 \mathrm{mg} \mathrm{K} \mathrm{kg}^{-1}$ at 0-15 cm depth and from 874 to $3318 \mathrm{mg} \mathrm{K} \mathrm{kg}^{-1}$ at $15-30 \mathrm{~cm} \mathrm{depth}^{-}$

Key words : Potassium, Forms, Distribution, Rice, Cowpea

How to cite this article : Divya, M., Jagadeesh, B.R., Srinivasa, D.K. and Yogesh, G.S. (2016).Effect of long term soil fertilizer application on forms and distribution of potassium in soil under rice- cowpea cropping system. Asian J. Soil Sci., 11 (1) : 9-19 : DOI : 10.15740/HAS/AJSS/11.1/9-19. 